\title{
Plasma Concentrations of Some Trace Element and Heavy Metals in Patients with Metastatic Colon Cancer*
}

\author{
Ozgur Emre ${ }^{1}$, Halit Demir ${ }^{1}$, Erkan Dogan ${ }^{2 \#}$, Ramazan Esen ${ }^{3}$, Tugba Gur ${ }^{4}$, Canan Demir ${ }^{5}$, \\ Edip Gonullu ${ }^{6}$, Nedim Turan ${ }^{7}$, Mehmet Fatih Özbay ${ }^{8}$
}

${ }^{1}$ Division of Biochemistry, Department of Chemistry, Science Faculty, Yuzuncu Yil University, Van, Turkey; ${ }^{2}$ Department of Medical Oncology, Medical Faculty, Yuzuncu Yil University, Van, Turkey; ${ }^{3}$ Department of Hematology, Medical Faculty, Yuzuncu Yil University, Van, Turkey; ${ }^{4}$ Division of Biochemistry, Health Faculty, Yuzuncu Yil University, Van, Turkey; ${ }^{5}$ Department of Biostatics, Faculty of Medicine, Yuzuncu Yil University, Van, Turkey; ${ }^{6}$ Department of Anesthesiology and Reanimation, Regional Training and Research Hospital of Van, Van, Turkey; ${ }^{7}$ Department of Medical Oncology, Faculty of Medicine, Gazi University, Ankara, Turkey; ${ }^{8}$ Department of Internal Medicine, Regional Training and Research Hospital of Van, Van, Turkey.

Email: ${ }^{\#}$ dr_erkandogan@yahoo.com

Received June $14^{\text {th }}, 2013$; revised July $12^{\text {th }}, 2013$; accepted July $19^{\text {th }}, 2013$

Copyright (C) 2013 Ozgur Emre et al. This is an open access article distributed under the Creative Commons Attribution License, which permits unrestricted use, distribution, and reproduction in any medium, provided the original work is properly cited.

\begin{abstract}
Purpose: It is well known that trace elements and heavy metals play a significant role in human health and disease. These elements play an important role in different metabolic pathways of cells and tissues. Trace element deficiency or excess is implicated in the development or progression of some cancers. We present a study which investigates serum/ plasma levels of trace-heavy elements in metastatic colon cancer patients and healthy subjects. Methods: Blood samples were collected from 29 healthy subjects and 40 patients with metastatic colon cancer in Oncology Department of Medical School of Yuzuncu Yil University. In both groups, the serum levels of copper $(\mathrm{Cu})$, magnesium $(\mathrm{Mg})$, lead $(\mathrm{Pb})$, chromium $(\mathrm{Cr})$, zinc $(\mathrm{Zn})$ selenium $(\mathrm{Se})$, manganese $(\mathrm{Mn})$, and cadmium $(\mathrm{Cd})$ were determined. Results: Higher levels of $\mathrm{Cu}, \mathrm{Mg}, \mathrm{Pb}, \mathrm{Cr}, \mathrm{Zn}, \mathrm{Mn}$ and $\mathrm{Cd}$ were seen in patients with metastatic colon cancer compared to healthy subjects and these findings were statistically significant $(\mathrm{p}<0.05)$. Se levels were noted to be lower in patients with colon cancer in comparison to healthy subjects and this finding was also statistically significant $(p<0.05)$. Conclusions: According to our findings there was significant diffence in trace elements and heavy metals levels between healthy subjects and metastatic colon cancer patients. Therefore heavy metal and trace elements may have prognostic significance in complex disorders including colon cancer. However, further comprehensive studies are needed in order to advance our understanding of the relationship between heavy metal and trace elements and their role in cancers.
\end{abstract}

Keywords: Colon Cancer; Trace Element; Heavy Metal; Essential Element

\section{Introduction}

Colorectal cancer (CRC) is the third most common cancer worldwide with an estimated one million new cases and a half million deaths each year [1,2]. Colorectal cancer is thought to result from a complex interaction between inherited susceptibility and environmental factors, as indicated by genetics and experimental and epidemicological studies [3-5]. Approximately $75 \%$ of patients have neither a clear family history nor any known predisposing condition [6]. According to observational studies that had been performed, development of CRC may be related to environmental factors such as high calorie

\footnotetext{
*Conflict of interest: None. Financial disclosure: None.

\#Corresponding author.
}

intake, high consumption of red meat (especially if overcooked), high consumption of saturated fat, low consumption of fruit, vegetables and fibre, high alcohol intake, obesity, cigarette smoking, and a sedentary lifestyle [7]. In recent years, the analysis of trace-heavy elements in human tissues has gained great interest due to the role that these elements play in biochemical and physiological processes. It is important to note trace-heavy elements also play an important role in human health and disease. These elements are necessary in different metabolic pathways of cells and tissues. Each of the essential and nonessential trace elements may be toxic if found in large concentrations in cells, tissues and fluids. Trace element deficiency or excess is implicated in the development or progression in some cancers $[8,9]$. 
The aim of our study was to investigate the difference between the serum level of some trace-mineral elements and heavy metals [copper $(\mathrm{Cu})$, magnesium $(\mathrm{Mg})$, lead $(\mathrm{Pb})$, chromium $(\mathrm{Cr})$, zinc $(\mathrm{Zn})$, manganese $(\mathrm{Mn})$, cadmium $(\mathrm{Cd})$ and selenium $(\mathrm{Se})]$, in patients with colon cancer and healthy group.

\section{Methods}

Between May 2008 and September 2010, a total of fourty patients with metastatic colon cancer and twenty nine healthy volunteers were enrolled. Venous blood samples of patients with meastatic colon cancer were obtained from the antecubital fossa veins in accordance with the guidelines set out in the Declaration of Helsinki. Informed consent was given by all the patients included in this study. The study was approved by the local ethics committee. Serum was separated by centrifugation and the samples were processed immediately. The serum samples were placed in deionised polyethylene tubes and kept at $-80^{\circ} \mathrm{C}$ (without thawing) until samples were analysed. Determination of serum concentrations of $\mathrm{Cu}, \mathrm{Mg}$, $\mathrm{Pb}, \mathrm{Cr}, \mathrm{Zn}, \mathrm{Mn}, \mathrm{Cd}$ and $\mathrm{Se}$ was performed by Atomic Absorption Spectrophotometer measurements, in which a UNICAM-929 spectrophotometer (Unicam Ltd, York Street, Cambridge, UK) was used.

All statistical analyses were carried out using the SPSS $^{\circledR}$ statistical software package (SPSS for Windows version 13.0, SPSS Inc., Chicago, Illinois, USA). The results were expressed as the Mean \pm Standard deviation (SD). The paired $t$ test was used for normally distributed variables. Wilcoxon signed rank test was used for variables that was not normally distributed. A two tailed $p$ value $<0.05$ was considered significant in all tests.

\section{Results}

In this study, we enrolled a total of fourty patients with metastatic colon cancer and twenty nine healthy volunteers in Oncology Department of Medical School of Yuzuncu Yil University. The median age was 67 (range, 45 to 76) years in patients with metastatic colon cancer and 69 (range, 45 to 76 ) in healthy volunteers. All serum biochemical parametres including hepatic functions of healthy volunteers and test groups were in normal limit. Among patients with metastatic colon cancer, twenty five were female and fifteen were male. While, among healthy volunteers, five of them were female and twenty four of them were male. $\mathrm{Cu}, \mathrm{Mg}, \mathrm{Pb}, \mathrm{Cr}, \mathrm{Zn}, \mathrm{Mn}$ and $\mathrm{Cd}$ value measured in colon cancer group were higher than the control group and this was statistically significant $(\mathrm{p}<$ $0.05)$. Se levels were noted to be lower in patients with colon cancer in comparison to healthy subjects ( $\mathrm{p}<$ 0.05).

All changes in the serum/plasma level of trace-mineral elements and heavy metals are summarized in Table 1.

\section{Discussion}

Malignant tumours arising in the colorectal mucosal epithelium destroy extracellular matrices such as the basement membrane, eventually becoming advanced cancers metastasising to the liver and other distant organs [10]. Although the risk factors do not fully explain variations in the incidence of complex disorders generally in cancer and also colon cancer in particular [11]. Epidemiological studies that had been performed cause perturbations in the trace elements in the etiology of a number of diseases including cancer. Normally the human body does need materials such as $\mathrm{Fe}, \mathrm{Zn}, \mathrm{Cu}, \mathrm{K}, \mathrm{Ca}, \mathrm{Na}, \mathrm{Mg}, \mathrm{Mn}, \mathrm{Cr}, \mathrm{Ni}$, $\mathrm{Mo}, \mathrm{Co}$ and Sn. Toxic concentrations of these compounds can occur due to individual life style, dietary habits or environmental conditions in the country of origin. Living organisms have developed mechanisms of utilising vital trace elements such as $\mathrm{Zn}$ and $\mathrm{Cu}$, and reducing the toxic influence of heavy metals like $\mathrm{Cd}, \mathrm{Hg}$ and $\mathrm{Pb}$ [12].

$\mathrm{Cu}$ is a redox-active transition metal that can participate in single electron reaction and catalyse formation of free radicals. Beside these properties, it is also an essential element for formation of hemoglobulin, myelin, collagen, and melanin. $\mathrm{Cu}$ has been suggested to play an important role in several disorders and normal immune function [13,14]. Nayak et al. performed a study in 20 patients affected by prostate and colon cancer, at the end of study they found that copper and ceruloplasmin levels were increased significantly in the cancer patients as compared to controls. They also speculate that determination of specific antioxidants (like ceruloplasmin)

Table 1. Serum levels of trace elements and heavy metals in groups.

\begin{tabular}{ccc}
\hline Parameter & $\begin{array}{c}\text { Control group } \\
(\mathrm{X} \pm \mathrm{SD})\end{array}$ & $\begin{array}{c}\text { Patients with colon } \\
\text { cancer }(\mathrm{X} \pm \mathrm{SD})\end{array}$ \\
\hline $\mathrm{N}=29$ & $\mathrm{~N}=40$ \\
$\mathrm{Cu}(\mathrm{mg} / \mathrm{L})^{*}$ & $0.151 \pm 0.0243$ & $0.241 \pm 0.1004$ \\
$\mathrm{Mg}(\mathrm{mg} / \mathrm{L})^{*}$ & $10.81 \pm 1.4231$ & $32.838 \pm 11.8095$ \\
$\mathrm{Zn}(\mathrm{mg} / \mathrm{L})^{*}$ & $2.488 \pm 0.3332$ & $5.134 \pm 1.865$ \\
$\mathrm{Mn}(\mathrm{mg} / \mathrm{L})^{*}$ & $0.2862 \pm 0.0486$ & $0.3326 \pm 0.2063$ \\
$\mathrm{Cd}(\mathrm{mg} / \mathrm{L})^{*}$ & $0.0027 \pm 0.0003$ & $0.1832 \pm 0.1441$ \\
$\mathrm{~Pb}(\mathrm{mg} / \mathrm{L})^{*}$ & $0.0268 \pm 0.0077$ & $0.1788 \pm 0.0705$ \\
$\mathrm{Se}(\mathrm{mg} / \mathrm{L})^{*}$ & $0.1138 \pm 0.0294$ & $0.05534 \pm 0.0233$ \\
$\mathrm{Cr}(\mathrm{mg} / \mathrm{L})^{*}$ & $0.0061 \pm 0.0016$ & $0.0325 \pm 0.0080$ \\
\hline
\end{tabular}

$\mathrm{X} \pm \mathrm{SD}=$ Mean \pm Standard Deviation. ${ }^{*}$ : difference between control group and patients with metastatic colon cancer is significant $(\mathrm{p}<0.05)$. 
and trace elements (like copper) may be of value in the early diagnosis of prostate and colon cancer [15]. In our study, the levels of $\mathrm{Cu}$ in patients with colon cancer were found to be significantly higher. This finding is consistent with Nayak's study. Therefore, serum Cu determinations may be important while assessing colon cancer patients.

Magnesium ( $\mathrm{Mg}$ ) is an essential mineral which plays a role in a number of cellular metabolic reactions. It plays a role in tumor biology via the regulation of oxidative stress, carcinogenesis, tumor progression, and angiogenesis [11,16-18]. It is thought that $\mathrm{Mg}$ also plays an important role in the differentiating cells. Optimal $\mathrm{Mg}$ intake may be prophylactic against initiation of some neoplasms or cancers. Since cancer cells have high metabolic requirements, it is not indicated (alone) in the treatment of cancer $[9,19]$. Mg deficiency can paradoxically increase the risk of, or protect against oncogenesis. Ac cording to animal studies dietary magnesium may play a role in the prevention of colorectal cancer, but data in humans are lacking. Larsson et al. stated that a high magnesium intake may reduce the occurrence of colorectal cancer in women [20]. In our study, in contrast to these findings, in patients with colon cancer; a significantly high level of Mg was detected. Although these results are challenging with results of previous studies. It should be kept in mind that previous studies are chemopreventive type. Therefore role of $\mathrm{Mg}$ on cancer formation may be diffent from role of $\mathrm{Mg}$ on cancer that has been already developped. For explaning this dilemma, further clinical studies are warranted.

High levels of lead $(\mathrm{Pb})$ exposure cause a number of negative effects for human health. There is some evidence that suggests lead exposure increases susceptibility to cancer. $\mathrm{Pb}$ may exert diverse toxic effects on cells, distrupting the ability of cells to develop appropriate and precise responses to genotoxic environmental agents. It may also interfere with the ability of DNA to repair itself after genotoxic insult. By binding histones, $\mathrm{Pb}$ may decrease the protection these proteins give DNA, directly increasing the exposure of DNA to damaging agents [21, 22]. In a study conducted by Lustberg M. et al. it was found that individuals who had high levels of lead had increased cancer-caused mortality due to lung cancer and nonlung cancer [23]. According to epidemiological study that was performed by Gwini et al., among workers exposed to inorganic lead, esophageal cancer was sevenfold greater among those with a blood lead level result above $30 \mu \mathrm{g} / \mathrm{dL}$ compared with population rates [24]. These results are consistent with our current study. Compare to the healthy group, $\mathrm{Pb}$ levels were significanly higher in colon cancer patients in our study. Therefore we think that high level of $\mathrm{Pb}$ has impact on development of colon cancer.
$\mathrm{Cr}$ is encountered in every branch of industry. $\mathrm{Cr}$ compounds, when in direct contact with skin and oral mucosa, can cause allergic dermatitis and skin ulcers. Teeth and tongue are dyed yellow. It was reported that via inhalation of dust and fumes, it may result in severe respiratory tract infections, pneumonia and lung cancer may occur more specifically with cumulative hexavalent chromium exposure [25,26]. It is also known that $\mathrm{Cr}$ has carcinogenic effect which occurs by DNA damage through base pair mutation, deletion, or oxygen radical attack on DNA [27]. In this study, we found that there was higher level of $\mathrm{Cr}$ in patients with colon cancer compared to healthy persons. This finding suggests that $\mathrm{Cr}$ may play a role in aetiology of colon cancer.

$\mathrm{Zn}$ is a component of many DNA repair proteins. It is also involved in a variety of general cellular functions such as cell signal transduction, transcription and replication [28]. $\mathrm{Zn}$ has important role in prevention of cancer formation by stabilizing the structure of deooxyribonucleic acid (DNA), ribonucleic acid (RNA) and ribosomes. Animal studies have shown that the administration of $\mathrm{Zn}$ may slow the progression of induced tumours and studies in humans also show that administration of $\mathrm{Zn}$ and other micronutrients may have therapeutic effects in patients with oral precancerous lesions [29]. Low serum Zn concentrations detected in some cancer such as esophageal carcinoma, ovarian cancer, cervical cancer [30,31]. By contrast, high serum level of $\mathrm{Zn}$ was detected in liver cancer [32]. In current study, high serum level of $\mathrm{Zn}$ was detected in patients with colon cancer. Thus, Zn may play different role in different types of cancers.

$\mathrm{Mn}$ is well known as an essential element that is required for health in trace amounts, but toxic at higher exposures. During the last decade, Mn has become an important component of gasoline industy instead of lead. It is therefore important to evaluate the potential cancer effects of Mn on the public. Spangler et al. performed an ecological study for evaluation of potential cancer effects of $\mathrm{Mn}$ and they reported that either groundwater or air concentrations of $\mathrm{Mn}$ is correlated with increase in allsite cancer rates including colon carcinoma [33]. In our current study, serum level of Mn was elevated in colon cancer patients with respect to control healthy group. Thus we think that high level of Mn might have relation with colon cancer.

The non-essential heavy metal $\mathrm{Cd}$ is a ubiquitous wide spread industrial and environmental contaminant that represents hazard to humans and wildlife. It is found in the air, soil and water and due to its extremely long half-life, accumulates in plants and animals. The main source of cadmium exposure for non-smoking human population is food. On the basis of data from animals and humans, $\mathrm{Cd}$ in food soon becomes absorbed in the blood, then becomes present in plasma, and later binds to red 
blood cells $[34,35]$. Cd is established toxic and carcinogenic metals [36,37]. Cd does not induce direct DNA damage, however it induces increase in reactive oxygen species (ROS) formation, which in turn induce DNA damage and can also interfere with cell signalling. According to epidemilogical studies $\mathrm{Cd}$ appears to be associated with overall cancer mortality in men and women. In men, Cd increases risk of lung cancer, pancreatic cancer, non-Hodgkin lymphoma and leukemia; while in women it increases risk of lung cancer, leukemia, ovarian and uterine cancer but risk of cancer is weaker than in men [38]. In this study, we found that serum Cd level was significantly higher in colon cancer patients compare to healthy group. This finding is important and needs to be verified with further clinical research.

Se is well known trace element which is involved in integral parts of antioxidant enzymes such as glutathione peroxidase [39]. In literature, significantly low serum level of Se had been detected in patients with prostate cancer $[40,41]$. In addition, the report by Clark et al. state that oral selenium supplementation significantly lowers incidence of lung, colorectal and prostate cancer [42]. Therefore, Se deficiency may contribute to formation of many types of malignant neoplasms including colon cancer. In our study, Se level was found significantly lower in colon cancer patients when compared to healthy subjects. Thus, low Se level is most probably related to development of colon carcinoma.

In conclusion, environmental factors have an important role in pathogenesis of cancer. Therefore heavy metal and trace elements may have prognostic significance in complex disorders including colon cancer. According to our results, it is possible that high Se level and low $\mathrm{Cu}$, $\mathrm{Mg}, \mathrm{Pb}, \mathrm{Cr}, \mathrm{Zn}, \mathrm{Mn}$ and $\mathrm{Cd}$ levels have a protective role in occurrence of colon cancer.

\section{REFERENCES}

[1] D. M. Parkin, F. Bray, J. Ferlay and P. Pisani, "Global Cancer Statistics, 2002," CA: A Cancer Journal for Clinicians, Vol. 55, No. 2, 2005, pp. 74-108. doi:10.3322/canjclin.55.2.74

[2] C. N. Arnold, A. Goel, H. E. Blum and C. R. Boland, "Molecular Pathogenesis of Colorectal Cancer: Implications for Molecular Diagnosis," Cancer, Vol. 104, No. 10, 2005, pp. 2035-2047. doi:10.1002/cncr.21462

[3] W. Willett, "The Search for the Causes of Breast and Colon Cancer," Nature, Vol. 338, No. 6214, 1989, pp. 389-394. doi:10.1038/338389a0

[4] B. Reddy, A. Engle, S. Katsifis, et al., "Biochemical Epidemiology of Colon Cancer: Effect of Types of Dietary Fiber on Fecal Mutagens, Acid, and Neutral Sterols in Healthy Subjects," Cancer Research, Vol. 49, No. 15, 1989, pp. 4629-4935.

[5] J. D. Potter, "Reconciling the Epidemiology, Physiology, and Molecular Biology of Colon Cancer," Journal of the
American Medical Association, Vol. 268, No. 12, 1992, pp. 1573-1577. doi:10.1001/jama.1992.03490120087033

[6] R. Lewis, A. Flynn, M. E. Dean, A. Melville, A. Eastwood and A. Booth, "Management of Colorectal Cancers," Quality \& Safety in Health Care, Vol. 13, No. 5, 2004, pp. 400-404. doi:10.1136/qshc.2004.011817

[7] NICE, "Guidance on Cancer Services: Improving Outcomes in Colorectal Cancers (Manual Update)," National Institute for Health and Clinical Excellence, London, 2004.

[8] K. Cavusoglu, A. S. Cakir, C. Kurtman, et al., "The Determination of Alteration in Plasma Trace Element Levels of Patients with Lung Cancer Received Radiotherapy," Firat University Medical Journal of Health Sciences, Vol. 22, No. 4, 2008, pp. 211-222.

[9] U. Cobanoglu, H. Demir, F. Sayir, et al., "Some Mineral, Trace Element and Heavy Metal Concentrations in Lung Cancer," Asian Pacific Journal of Cancer Prevention, Vol. 11, No. 5, 2010, pp. 1383-1388.

[10] L. A. Liotta, "Tumor Invasion and Metastasis Role of Extracellular Matrix," Rhodes Memorial Award Lecture, Cancer Research, Vol. 46, No. 1, 1986, pp. 1-7.

[11] W. Mertz, "The Essential Trace Elements," Science, Vol. 13, No. 4514, 1981, pp. 1332-1338. doi:10.1126/science.7022654

[12] M. Solioz, A. Odermatt and R. Krapf, "Copper Pumping ATPases: Common Concepts in Bacteria and Man," FEBS Letters, Vol. 346, No. 1, 1994, pp. 44-47. doi:10.1016/0014-5793(94)00316-5

[13] J. C. Wallwork, "Cu and Central Nervous System," Progress in Food \& Nutrition Science, Vol. 11, No. 2, 1987, pp. 203-247.

[14] F. Sayır, S. Kavak, I. Meral, H. Demir, N. Cengiz and U. Cobanoğlu, "Effects of Crush and Axotomy on Oxidative Stress and Some Trace Element Levels in Phrenic Nerve of Rats," Brain Research Bulletin, Vol. 92, No. 1, 2011, pp. 84-88.

[15] S. B. Nayak, V. R. Bhat, D. Upadhyay and S. L. Udupa, "Copper and Ceruloplasmin Status in Serum of Prostate and Colon Cancer Patients," Indian Journal of Physiology and Pharmacology, Vol. 47, No. 1, 2003, pp. 108-110.

[16] K. A. Lapidos, E. C. Woodhouse, E. C. Kohn and L. Masiero, "Mg(++)-Induced Endothelial Cell Migration: Substratum Selectivity and Receptor-Involvement," Angiogenesis, Vol. 4, No. 1, 2001, pp. 21-28. doi:10.1023/A:1016619414817

[17] J. Anastassopoulou and T. Theophanides, "MagnesiumDNA Interactions and the Possible Relation of Magnesium to Carcinogenesis. Irradiation and Free Radicals," Critical Reviews in Oncology/Hematology, Vol. 42, No. 1, 2002, pp. 79-91. doi:10.1016/S1040-8428(02)00006-9

[18] H. Rubin, "Central Roles of $\mathrm{Mg}^{2+}$ and MgATP2- in the Regulation of Protein Synthesis and Cell Proliferation: Significance for Neoplastic Transformation," Advances in Cancer Research, Vol. 93, 2005, pp. 1-58. doi:10.1016/S0065-230X(05)93001-7

[19] P. Collery, L. J. Anghileri, P. Coudoux, et al., "Magnesium and Cancer: Clinical Data," Magnesium Bulletin, 
Vol. 3, No. 1, 1981, pp. 11-20.

[20] S. C. Larsson, L. Bergkvist and A. Wolk, "Magnesium Intake in Relation to Risk of Colorectal Cancer in Women," JAMA, Vol. 293, No. 1, 2005, pp. 86-89. doi:10.1001/jama.293.1.86

[21] E. K. Silbergeld, M. Waalkes and J. M. Rice, "Lead as a Carcinogen: Experimental Evidence and Mechanisms of Action," American Journal of Industrial Medicine, Vol. 38, No. 3, 2000, pp. 316-323. doi:10.1002/1097-0274(200009)38:3<316::AID-AJIM11 $>3.0 . \mathrm{CO} ; 2-\mathrm{P}$

[22] B. Quintanilla-Vega, D. Hoover, W. Bal and E. K. Silbergeld, "Lead Effects on Protamine-DNA Binding," American Journal of Industrial Medicine, Vol. 38, No. 3, 2000, pp. 324-329. doi:10.1002/1097-0274(200009)38:3<324::AID-AJIM12 $>3.0 . \mathrm{CO} ; 2-\mathrm{R}$

[23] M. Lustberg and E. Silbergeld, "Blood Lead Levels and Mortality," Archives of Internal Medicine, Vol. 162, No. 21, 2002, pp. 2443-2449. doi:10.1001/archinte.162.21.2443

[24] S. Gwini, E. MacFarlane, A. Del Monaco, et al., "Cancer Incidence, Mortality, and Blood Lead Levels among Workers Exposed to Inorganic Lead," Annals of Epidemiology, Vol. 22, No. 4, 2012, pp. 270-276. doi:10.1016/j.annepidem.2012.01.003

[25] D. Ozmen, B. Boydak, B. Ersoz, et al., "After Cardiac Surgery Changes in Serum Iron, Zinc, Copper Levels and the Transportproteins of the Elements," Journal of Biochemistry, Vol. 13, No. 1, 1993, pp. 25-33.

[26] H. J. Gibb, P. S. Lees, P. F. Pinsky and B. C. Rooney, "Lung Cancer among Workers in Chromium Chemical Production," American Journal of Industrial Medicine, Vol. 38, No. 2, 2000, pp. 115-126.

doi:10.1002/1097-0274(200008)38:2<115::AID-AJIM1> 3.0.CO;2-Y

[27] J. R. Landolph, "Molecular Mechanisms of Transformation of $\mathrm{C} 3 \mathrm{H} / 10 \mathrm{~T} 1 / 2 \mathrm{C} 18$ Mouseembryo Cells and Diploid Human Fibroblasts by Carcinogenic Metal Compounds," Environmental Health Perspectives, Vol. 102, No. 3, 1994, pp. 119-125.

[28] J. Xia, J. D. Browing, B. L. O’Dell, “Decreased Plasma Membrane Thiol Concentration Is Associated with Increased Osmotic Fragility of Erythrocyte in Zinc-Deficient Rats," Journal of Nutrition, Vol. 129, No. 4, 1999, pp. 814-819.

[29] K. Krishnaswamy, M. P. Prasad, T. P. Krishna, V. V. Annapurna and G. A. Reddy, "A Case Study of Nutrient Intervention of Oral Precancerous Lesions in India," European Journal of Cancer Part B: Oral Oncology, Vol. 31B, No. 1, 1995, pp. 41-48. doi:10.1016/0964-1955(94)00027-2

[30] N. A. Dar, M. M. Mir, I. Salam, et al., "Association between Copper Excess, Zinc Deficiency, and TP53 Mutations in Esophageal Squamous Cell Carcinoma from Kashmir Valley, India: A High Risk Area," Nutrition and Cancer, Vol. 60, No. 5, 2008, pp. 585-591. doi:10.1080/01635580802290231
[31] M. Yaman, G. Kaya and M. Simsek, "Comparison of Trace Element Concentrations in Cancerous and Noncancerous Human Endometrial and Ovary Tissues," International Journal of Gynecological Cancer, Vol. 17, No. 1, 2007, pp. 220-228. doi:10.1111/j.1525-1438.2006.00742.x

[32] V. M. Karlinskiĭ and G. G. Bogomolova, "Change in Zinc Metabolism in Malignant Neoplasms," Vopr Onkol, Vol. 31, No. 2, 1985, pp. 25-29.

[33] J. G. Spangler and J. C. Reid, "Environmental Manganese and Cancer Mortality Rates by County in North Carolina: An Ecological Study," Biological Trace Element Research, Vol. 133, No. 2, 2010, pp. 128-135. doi:10.1007/s12011-009-8415-9

[34] M. Nordberg, "Studies on Metallothionein and Cadmium," Environmental Research, Vol. 15, 1978, pp. 381-404. doi:10.1016/0013-9351(78)90120-2

[35] A. C. Bobocea, E. T. Fertıg, P. Mihaela, et al., "Cadmium and Soft Laser Radiation Effects on Human T Cells Viability and Death Style Choices," Romanian Journal of Biophysics, Vol. 18, No. 3, 2008, pp. 179-193.

[36] T. S. Nawrot, L. Thijs, E. M. Den Hond, H. A. Roels and J. A. Staessen, "An Epidemiological Re-Appraisal of the Association between Blood Pressure and Blood Lead: A Meta-Analysis," Journal of Human Hypertension, 2002, Vol. 16, No. 2, pp. 123-131. doi:10.1038/sj.jhh.1001300

[37] B. Messner, M. Knoflach, A. Seubert, et al., "Cadmium Is a Novel and Independent Risk Factor for Early Atherosclerosis Mechanisms and in Vivo Relevance," Arteriosclerosis, Thrombosis, and Vascular Biology, Vol. 29, No. 9, 2009, pp. 1392-1398. doi:10.1161/ATVBAHA.109.190082

[38] S. V. Adams, M. N. Passarelli and P. A. Newcomb, "Cadmium Exposure and Cancer Mortality in the Third National Health and Nutrition Examination Survey Cohort," Occupational and Environmental Medicine, Vol. 69, No. 2, 2012, pp. 153-156. doi:10.1136/oemed-2011-100111

[39] M. T. Ruffin and C. L. Rock, "Do Antioxidants Still Have a Role in the Prevention of Human Cancer?" Current Oncology Reports, 2001, Vol. 3, No. 4, pp. 306-313. doi:10.1007/s11912-001-0082-8

[40] H. Ozmen, F. A. Erulas, F. Karatas, A. Cukurovali and O. Yalcin, "Comparison of the Concentration of Trace Metals (Ni, Zn, Co, Cu and Se), Fe, vitamins A, C and E, and Lipid Peroxidation in Patients with Prostate Cancer," Clinical Chemistry and Laboratory Medicine, Vol. 44, No. 2, 2006, pp. 175-179. doi:10.1515/CCLM.2006.032

[41] M. O. Akiibinu, A. O. Ogundahunsi, O. I. Kareem, et al., "Trace Metals and Oxidative Metabolic Changes in Malignant Prostate Cancer Patients," African Journal of Biochemistry Research, Vol. 5, No. 3, 2011, pp. 102-105.

[42] L. C. Clark, G. F. Combs Jr, B. W. Turnbull, et al., "Effects of Selenium Supplementation for Cancer Prevention in Patients with Carcinoma of the Skin. A Randomized Controlled Trial. Nutritional Prevention of Cancer Study Group," Journal of the American Medical Association, 1996, Vol. 276, No. 24, pp. 1957-1963. doi:10.1001/jama.1996.03540240035027 


\section{Abbreviation}

Copper $(\mathrm{Cu})$

Magnesium (Mg)

Zinc (Zn)

Manganese (Mn)

Cadmium (Cd)

Lead $(\mathrm{Pb})$

Selenium (Se)

Chromium (Cr) 